Abstracta Iranica Abstracta Iranica

Revue bibliographique pour le domaine irano-aryen

Volume 40-41 | 2019

Comptes rendus des publications de 2017-2018

\title{
Andrea Gariboldi. "Pratiche economiche e monetali nei documenti pahlavi del Tabaristān (VIII sec.)"
}

\section{Rika Gyselen}

\section{Q OpenEdition}

9 Journals

\section{Édition électronique}

URL : https://journals.openedition.org/abstractairanica/49658

DOI : 10.4000/abstractairanica.49658

ISBN : 1961-960X

ISSN : 1961-960X

Éditeur :

CNRS (UMR 7528 Mondes iraniens et indiens), Éditions de l'IFRI

Référence électronique

Rika Gyselen, «Andrea Gariboldi. "Pratiche economiche e monetali nei documenti pahlavi del

Tabaristān (VIII sec.)" », Abstracta Iranica [En ligne], Volume 40-41 | 2019, document 27, mis en ligne le 30 octobre 2019, consulté le 21 septembre 2021. URL : http://journals.openedition.org/ abstractairanica/49658 ; DOI : https://doi.org/10.4000/abstractairanica.49658

Ce document a été généré automatiquement le 21 septembre 2021.

Tous droits réservés 


\section{Andrea Gariboldi. "Pratiche economiche e monetali nei documenti pahlavi del Tabaristān (VIII sec.)"}

Rika Gyselen 


\section{RÉFÉRENCE}

Andrea Gariboldi. "Pratiche economiche e monetali nei documenti pahlavi del

Tabaristān (VIII sec.)”, Electrum, 24, 2017, p. 253-262

1 Après une introduction sur l'histoire du 'Tabarestān', l'auteur aborde la numismatique du Tabarestān et en particulier la question du poids $( \pm 2 \mathrm{~g})$ et du diamètre $(22 / 25 \mathrm{~mm})$ de la monnaie d'argent du Tabarestān. Normalement désigné comme 'demi-drahm' par rapport à la drahm sassanide ( $\pm 4 \mathrm{~g}$ et $\pm 35 \mathrm{~mm})$, l'auteur suggère qu'il faut plutôt placer le monnayage du Tabarestān dans le cadre des valeurs utilisées par les Arabes pour leur monnayage réformé et non dans une tradition sassanide.

2 L'objectif principal est l'examen de certains documents de "l'archive du Tabarestān ", datant de la première moitié du VIIIe siècle, dont certains passages comportent les termes drahm et stēr. L'auteur suggère que le $d r a h m$ pourrait se référer à la pièce d'argent du Tabarestān qu'il considère comme une drahm 'légère' et que le terme stēr serait ici utilisé dans le sens d'un poids et non pas comme le quadruple de la drahm.

Il reste à prouver que le terme drahm dans les documents se réfère à la monnaie du Tabarestān (2g) et n'est pas simplement un poids $( \pm 4 g)$ comme dans les inscriptions moyen-perses sur l'argenterie. C'est ce que semble indiquer une inscription sur un plat du 'Tabarestān' de la même époque (Rika Gyselen, La Géographie administrative de l'empire sassanide. Les témoignages épigraphiques en moyen-perse [Res Orientales, XXV], Bures-surYvette, Groupe pour l'Étude de la Civilisation du Moyen-Orient, 2019, p. 241).

\section{AUTEURS}

\section{RIKA GYSELEN}

CNRS, Mondes iranien et indien 